\title{
KARAKTERISASI DAN AKTIVITAS ANTIOKSIDAN SERAT PANGAN DARI DAGING BUAH PALA (Myristica fragrans Houtt)
}

\author{
Christina Tang Dareda ${ }^{1}$, Edi Suryanto ${ }^{1 *}$ dan Lidya I. Momuat ${ }^{1}$ \\ ${ }^{1}$ Program Studi Kimia, Fakultas Matematika dan Ilmu Pengetahuan Alam \\ Universitas Sam Ratulangi Manado
}

\begin{abstract}
ABSTRAK
Tujuan dari penelitian ini untuk mengetahui karakteristik fisikokimia dan potensi antioksidan serat pangan dari daging buah pala. Parameter yang digunakan adalah komposisi proksimat, serat pangan, kandungan hemiselulosa, selulosa, lignin, karakteristik gugus fungsi, aktivitas antioksidan, dan kapasitas penangkal nitrit. Hasil karakteristik secara fisik dengan analisis Fourier Transform Infra Red (FT-IR) menunjukkan adanya daerah serapan gugus $-\mathrm{OH},-\mathrm{CH},-\mathrm{CH}_{2}, \mathrm{C}-\mathrm{O}-\mathrm{C}$ yang merupakan identifikasi adanya selulosa pada sampel. Hasil analisis Particle Size Analysis (PSA) menunjukkan ukuran partikel dari daging buah pala $137.08 \mu \mathrm{m}$. Analisis X-ray Difraction (XRD) menunjukkan adanya karakteristik dari selulosa dari sampel daging buah pala. Hasil karakterisasi secara kimia menunjukkan komposisi kimia dari daging buah pala seperti air $(9.11 \%)$, abu (3.43\%), lemak $(1.81 \%)$, protein $(4.04 \%)$, serat kasar $(17.57 \%)$, serat pangan tak larut $(48.61 \%)$, serat pangan terlarut $(1.67 \%)$, serat pangan total $(50.28 \%)$, hemiselulosa $(10.72 \%)$, selulosa $(15.66 \%)$ dan lignin $(19.09 \%)$. Hasil pengujian aktivitas antioksidan menunjukkan bahwa ekstrak fenolik bebas daging buah pala lebih besar dibandingkan dengan ekstrak fenolik terikat daging buah pala dan aktivitas penangkal nitrit dari daging buah pala menunjukkan bahwa ekstrak fenolik bebas daging buah pala lebih besar dibandingkan dengan ekstrak fenolik terikat daging buah pala.
\end{abstract}

Kata kunci : Karakterisasi, antioksidan, serat pangan, daging buah pala

\begin{abstract}
The purpose of this study was to determine the physicochemical characteristics and antioxidant potential of food fiber from nutmeg meat. The parameters used are proximate composition, dietary fiber, hemicellulose content, cellulose, lignin, functional group characteristics, antioxidant activity, and nitrite repellent capacity. The results of physical characteristics with Fourier Transform Infra Red (FT-IR) analysis showed the absorption area of the $-\mathrm{OH},-\mathrm{CH},-\mathrm{CH}_{2}$, C-O-C groups which was an identification of cellulose in the sample. The results of the Particle Size Analysis (PSA) show the particle size of the nutmeg flesh $137.08 \mu \mathrm{m}$. X-ray Difraction (XRD) analysis showed the characteristics of cellulose from nutmeg meat samples. Chemical characterization results showed the chemical composition of nutmeg meat such as water $(9.11 \%)$, ash $(3.43 \%)$, fat $(1.81 \%)$, protein $(4.04 \%)$, crude fiber $(17.57 \%)$, insoluble food fiber $(48.61 \%)$, dissolved food fiber $(1.67 \%)$, total food fiber $(50.28 \%)$, hemicellulose $(10.72 \%)$, cellulose $(15.66 \%)$ and lignin (19.09\%). The results of antioxidant activity testing showed that the extract of phenolic-free nutmeg was greater than the phenolic extract bound to nutmeg meat and the nitrite-antidote activity of nutmeg showed that the phenolic extract of nutmeg-free flesh was greater than that of phenolic extract bound to nutmeg meat.
\end{abstract}

Keywords: Characterization, antioxidant, dietary fiber, nutmeg

\section{PENDAHULUAN}

Tanaman pala merupakan salah satu produk pertanian yang banyak dihasilkan di Negara Indonesia. Pada kegiatan pertanian pala akan menghasilkan limbah buah pala $30-40 \%$ yang terdiri dari daging pala dan tempurung biji. Menurut Direktorat Jenderal Perkebunan (2018), produksi tanaman pala di Sulawesi Utara tahun 2018 sebesar 36,242 ton/tahun, dengan perbandingan hasil biji pala dengan daging buah pala adalah 1:4 sehingga presentasi limbah pala yang dihasilkan tiap tahunnya sekitar $80 \%$. Daging pala memilki kandungan tannin 12,34-
$15,30 \%$ dan ditemukan juga pektin yang merupakan salah satu komponen serat pangan yang terkandung di dalam buah pala dalam bentuk getah yang berwarna kecoklatan (Fidriany et al., 2004). Menurut penelitian yang telah dilakukan oleh Marzuki et al. (2008) menyebutkan bahwa ditemukan kandungan lemak serta protein dalam daging buah pala. Beberapa penelitian lainnya melaporkan adanya kandungan fitokimia pada daging buah pala diantaranya flavonoid dan alkaloid (Arrizqiyani et al., 2018).

Mikronisasi adalah proses mengurangi ukuran rata-rata dari partikel bahan padat,

\footnotetext{
* Korespondensi:

Telepon: +62 853-9856-6170

Email: edi7suryanto@gmail.com

DOI: https://doi.org/10.35799/cp.13.1.2020.29661
} 
sehingga meningkatkan sifat permukaan baik seperti kemampuan dispersi dan peningkatan kelarutan (Blagden et al., 2007). Chau et al. (2007), melaporkan bahwa efek perlakuan mikronisasi terhadap tepung serat pangan memberikan perbedaan sifat fisikokimia dari pada bahan baku aslinya.

Kandungan serat pangan dan fitokimia yang terkandung dalam daging buah pala dapat berpotensi sebagai antioksidan serat pangan yang berasal dari daging buah pala. Sejauh ini belum ada informasi penelitian tentang karakterisasi dan aktivitas antioksidan serat pangan buah pala setelah dimikronisasi. Untuk itulah penelitian ini dilakukan.

\section{BAHAN DAN METODE}

\section{Alat dan bahan}

Alat yang digunakan yaitu kertas saring, aluminium foil, timbangan analitik, rotary evaporator, oven, pipet volume, gelas piala, alat untuk blender, tabung reaksi, penangas air, labu erlenmeyer, labu volumetric, corong gelas, corong pisah, cawan porselen, desikator, vortex, rotary evaporator, milling (fomac tipe FCT-Z200 tegangan $220 \mathrm{~V}$ daya $1 \mathrm{KW}$ frekuensi $50-60 \mathrm{hz}$ kecepatan putar $28.000 \mathrm{rpm}$ ), ayakan 35 dan 200 mesh, rak tabung, krus porselin, micro pipet, gelas ukur, petridish, sudip, botol vial, tanur, spektrofotometer UV-Vis (shimadzu), PSA, XRD, Spektrofotometer FTIR dan sonikator (cole-parmer instrument serial no: 45066 L frekuensi $20 \mathrm{khz}$, daya 130 watt). Bahan yang digunakan dalam penelitian ini adalah sampel buah pala yang diperoleh dari desa Moronge Kecamatan Moronge Kabupaten Kepulauan Talaud Sulawesi Utara. Bahan yang digunakan yaitu, akuades, Petroleum eter, Etanol, alumunium foil, kertas lakmus, Natrium karbonat, Reagen Folin-Ciocalteu, Aseton, Buffer fosfat, Asam klorida, Natrium hidroksida, Asam sulfat, DPPH, N-(1naphthyl)ethylenediamine, Asam sulfanilat, dan Natrium nitrit.

\section{Preparasi}

Daging pala dicuci bersih pada air mengalir setelah itu direbus dengan air mendidih selama 5 menit kemudian daging pala dipisahkan dari kulitnya. Diambil $1 \mathrm{~kg}$ daging buah pala yang telah dipisahkan dari kulitnya kemudian dipotong kecil-kecil dan dikeringkan dalam oven pada 50 - 60 oC selama 3 hari. Setelah kering daging buah pala diblender dan diayak menggunakan ayakan 35 mesh. Selanjutnya dihaluskan dengan alat milling (Fomac tipe FCT-Z200 tegangan 220 $\mathrm{V}$ daya $1 \mathrm{KW}$ frekuensi $50-60 \mathrm{~Hz}$ kecepatan putar $28.000 \mathrm{rpm})$ kemudian diayak menggunakan ayakan 200 mesh.

\section{Karakterisasi fisik}

Serbuk daging buah pala yang telah dihasulkan dengan ayakan 200 mesh kemudian dikarakterisasi menggunakannm Fourier Transform Infra-Red (FT-IR), Particles Sized Analyzer (PSA) dan X-ray Difraction (XRD) untuk mengetahui karakteristik fisik dari sampel.

\section{Karakterisasi kimia}

Komposisi kimia tepung serat pangan buah pala, kulit buah pala, dan daging pala meliputi uji kadar air, uji kadar abu, uji kadar protein, uji kadar lemak, uji serat kasar dan karbohidrat by different (Sudarmadji et al., 1997). Penentuan kandungan hemiselulosa, selulosa dan lignin menggunakan metode Datta (1981). Penentuan kandungan serat pangan menggunakan metode AOAC (1995).

\section{Ekstraksi daging buah pala}

Serbuk daging buah pala yang sudah diayak dengan ayakan 200 mesh ditimbang Sebanyak $5 \mathrm{~g}$, dimaserasi dengan $50 \mathrm{~mL}$ pelarut etanol $80 \%$ selama 24 jam kemudian disaring. Filtrat hasil maserasi dipekatkan menggunakan rotary evaporator dan ditimbang sebagai ekstrak fenolik bebas. Selanjutnya residu dihidrolisis dengan $100 \mathrm{~mL} \mathrm{NaOH} 2 \mathrm{M}$, diaduk dan diinkubasi pada suhu kamar selama 1 jam. Selanjutnya, campuran dinetralkan dengan penambahan $\mathrm{HCl}$ sampai $\mathrm{pH} 6$ dan diekstraksi sebanyak 3 kali dengan pelarut etil asetat sampai bening. Fraksi etil asetat dievaporasi pada $40{ }^{\circ} \mathrm{C}$ dan dikeringkan dalam oven sehingga didapat ekstrak fenolik terikat. kedua ekstrak yang diperoleh ditimbang dan disimpan pada suhu 0

${ }^{\mathrm{o}} \mathrm{C}$ sebelum dianalisis kandungan total fenolik dan aktivitas antioksidan.

\section{Penentuan kandungan total fenolik}

Kandungan total fenolik ditentukan menggunakan metode Jeong et al. (2004). Sebanyak $0,1 \quad \mathrm{~mL}$ sampel $1000 \mu \mathrm{g} / \mathrm{mL}$ dimasukkan ke dalam tabung reaksi, lalu ditambahkan $0,1 \mathrm{~mL}$ reagen Folin Ciocalteu $50 \%$ dalam tabung reaksi dan kemudian campuran divortex selama 3 menit. Setelah interval waktu 3 menit, ditambahkan $2 \mathrm{~mL}$ larutan $\mathrm{Na}_{2} \mathrm{CO}_{3} 2$ 
$\%$, kemudian campuran diinkubasi dalam ruang gelap selama 30 menit.Selanjutnya dibaca dibaca absorbansinya pada $\lambda \quad 750 \mathrm{~nm}$ dengan menggunakan spektrofotometer UV-Vis.

\section{Penentuan kandungan antioksidan}

Penangkal radikal bebas menggunakan metode DPPH sesuai yang digunakan Molyneux (2004). Sebanyak $1 \mathrm{~mL}$ ekstrak kental dengan konsentrasi $1000 \mu \mathrm{g} / \mathrm{mL}$ ditambahkan kedalam 2 $\mathrm{mL}$ DPPH 0,1 mM. Campuran selanjutnya dikocok dan diinkubasi pada suhu kamar selama 30 menit ditempat gelap. Larutan ini selanjutnya diukur absorbansinya pada $\lambda$ maks $517 \mathrm{~nm}$. Data hasil pengukuran absorbansi dianalisa persentase aktivitas antioksidannya menggunakan persamaan berikut :

$$
\mathrm{APRB}=\left(1-\frac{\text { absorbansi sampel }}{\text { absorbansi kontrol }}\right) \times 100 \%
$$

\section{Penentuan kapasitas penangkal ion nitrit}

Kapasitas penangkal nitrit ditentukan menggunakan metode Zhang et al. (2009). $2 \mathrm{~mL}$ Natrium nitrit $5 \mathrm{mg} / \mathrm{L}$ dicampur dengan $3 \mathrm{~mL}$ ekstrak dalam labu $25 \mathrm{~mL}$ pada suhu kamar selama 30 menit. Larutan campuran dicampur dengan $1 \mathrm{~mL}$ asam sulfanilat $0,4 \%$ distirer selama 5 menit diikuti penambahan $0,5 \mathrm{~mL} \mathrm{~N}-(1-$ Naphthyl)ethylenediamine $0,1 \%$ dan volume disesuaikan menjadi $25 \mathrm{~mL}$ dengan aquades. Larutan didiamkan selama 15 menit dan diukur absorbansi menggunakan Spektrofotometer UVVis pada $\lambda 538 \mathrm{~nm}$. Persentase kapasitas penangkal ion nitrit (KPIN) dihitung menggunakan rumus:

$$
\operatorname{KPIN}(\%)=\left(\frac{\mathrm{A}_{0}-\left(\mathrm{A}_{1}-\mathrm{A}_{2}\right)}{\mathrm{A}_{0}}\right) \times 100 \%
$$

Keterangan: $\quad \mathrm{A}_{0}=$ Absorbansi $\mathrm{NaNO}_{2} ; \mathrm{A}_{1}=$ Absorbansi $\mathrm{NaNO}_{2}$ dan Ekstrak; $\mathrm{A}_{2}=$ Absorbansi ekstrak

\section{HASIL DAN PEMBAHASAN}

\section{Rendemen daging buah pala}

Rendemen daging buah pala dihitung untuk mengetahui banyaknya rendemen yang dihasilkan untuk perlakuan pengeringan daging buah pala. Dari $1 \mathrm{~kg}$ daging buah pala yang telah dikeringkan, digiling dan diayak menggunakan ayakan 35 mesh menghasilkan rendemen sebesar $12.87 \%$. Selanjutnya hasil mikronisasi dengan alat Fomac tipe FCT-Z200 dan diayak menggunakan 200 mesh diperoleh rendemen sebesar $71.5 \%$. Berdasarkan hasil rendemen yang diperoleh, alat milling dapat menghaluskan sampel hingga berukuran mikro.

\section{Karakteristik kimia daging buah pala}

Berdasarkan hasil karakteristik kimia daging buah pala melalui analisa proksimat, terlihat bahwa daging buah pala memilki kandungan air, abu, serat kasar dan karbohidrat yang tinggi sedangkan untuk kandungan protein dan lemak daging buah pala relatife rendah.

Tabel 1. Analisa proksimat daging buah pala

\begin{tabular}{lc}
\hline \multicolumn{1}{c}{ Komponen } & DG \\
\hline Kadar Air (\%) & $9,11 \pm 0,35$ \\
Kadar Abu (\%) & $3,43 \pm 0.13$ \\
Kadar Protein (\%) & $4.04 \pm 0.05$ \\
Kadar Lemak (\%) & $1,81 \pm 0.81$ \\
Serat Pangan Larut (\%) & $1.67 \pm 0.03$ \\
Serat Pangan Tak Lrut (\%) & $48.61 \pm 0.21$ \\
Serat Pangan Total (\%) & $50.28 \pm 0.17$ \\
Kadar Karbohidrat (\%) & $81.28 \pm 1.42$ \\
\hline
\end{tabular}

Dari Tabel 1 kandungan air yang terkandungan dalam sampel $9.11 \%$ hal ini diduga oleh suhu dan waktu pengeringan pada sampel, dimana suhu yang digunakan $55-60{ }^{\circ} \mathrm{C}$ dengan waktu pengeringan 3 hari, setiap kenaikan suhu dan semakin lama waktu pengeringan maka kandungan air pada sampel semakin rendah. Kadar abu daging buah pala sebesar 3.43\% hal ini menunjukkan banyaknya komponen anorganik yang terkandung dalam sampel karena kadar abu pada suatu bahan pangan menunjukkan komponen anorganik yang terkandung didalamnya. Kandungan protein dari daging buah pala yaitu $4.04 \%$ hal ini dipengaruhi oleh suhu selama preparasi sampel. Sejalan dengan pendapat Yuniarti, et al (2013), bahwa pemanasan yang terlalu lama dengan suhu yang tinggi akan menyebabkan protein terdenaturasi. Kandungan lemak pada daging buah pala sebesar $1.81 \%$ hal ini kemungkinan disebabkan oleh lama perebusan sampel sehingga masih memiliki kandungan lemak didalamnya. Hasil serat pangan total $50.28 \%$ yang didapat dari penambahan serat pangan tak larut $48.61 \%$ dan serat pangan larut sebesar $1.67 \%$. Kandungan serat pangan larut dari daging buah pala diduga ikut larut dalam media perebusan sampel sehingga menyebabkan kandungan serat pangan larut kecil dibandingkan dengan serat pangan tak larut. Hal ini sejalan dengan pendapat Astawan \& Wresdiyati (2004) bahwa serat pangan tidak larut tidak dapat larut di dalam air panas maupun air dingin. 
Kandungan hemiselulosa, selulosa dan lignin

Penentuan kandungan hemiselulosa, selulosa dan lignin ditentukan menggunakan metode yang dijelaskan oleh Datta (1982) yaitu metode dengan prinsip gravimetri. Hasil pengujian kandungan hemiselulosa, selulosa dan lignin yang ditunjukkan pada Tabel 2 .

Tabel 2. Kandungan hemiselulosa, selulosa dan lignin

\begin{tabular}{lc}
\hline \multicolumn{1}{c}{ Kandungan } & DG \\
\hline Hemiselulosa (\%) & $9,11 \pm 0,35$ \\
Selulosa (\%) & $3,43 \pm 0.13$ \\
Lignin (\%) & $4.04 \pm 0.05$ \\
\hline
\end{tabular}

Berdasarkan Tabel 2 daging buah pala memiliki kandungan hemiselulosa, selulosa dan lignin. Tinggi rendahnya kandungan hemiselulosa, selulosa dan lignin sangat dipengaruhi oleh larutan alkali saat pemisahan komponen hemiselulosa, selulosa dan lignin. Lignin yang mempunyai struktur yang amorf sehingga sebagian komponen lignin ikut larut dalam pelarut dan menyebabkan tingginya komponen hemiselulosa banyak terekstraksi.

\section{Pengujian (Fourier Transform Infra-Red) FT- IR}

Spektroskopi FT-IR digunakan untuk mengetahui struktur kimia yang dihasilkan dari tepung daging buah pala. Spektrum FT-IR dari tepung daging buah pala (DG) dan mikrokristal selulosa (SMK) dapat dilihat pada Gambar 1.

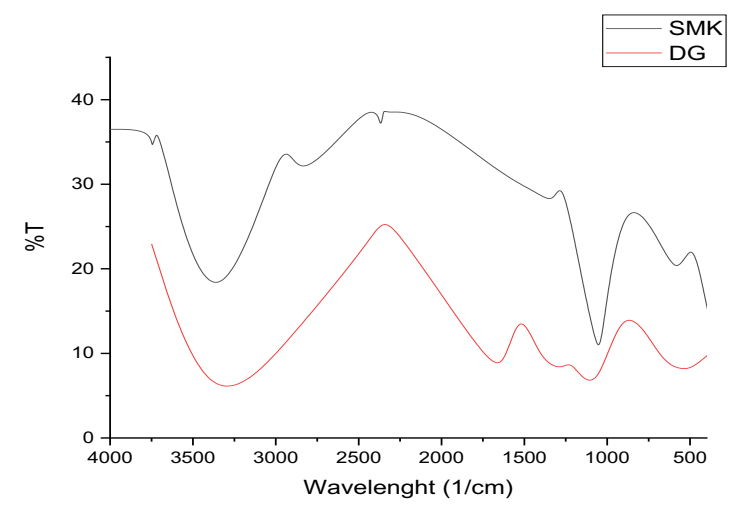

Gambar 1. Spektrum FT-IR dari tepung daging buah pala (DG) dan standar mikrokristalin selulosa (SMK)

Hasil spektra pada Gambar 1 dari standar selulosa menunjukkan adanya serapan pada bilangan gelombang $3371.57 \mathrm{~cm}^{-1}$ dan untuk DG $3417.86 \mathrm{~cm}^{-1}$ mengindikasikan adanya renggangan $\mathrm{OH}$ dari gugus hidroksil yang berasal dari selulosa (Milovanovic et al., 2016). Pada bilangan gelombang 2931.8 untuk DG $\mathrm{cm}^{-1}$ daerah serapan ini menunjukkan vibrasi C-H dari selulosa, untuk bilangan gelombang selulosa standar muncul pada $2900.94 \mathrm{~cm}^{-1}$ yang mana mengindikasikan kehadiran senyawa polosakarida (Abbasi et al., 2016). Bilangan gelombang $1620 \mathrm{~cm}^{-1}$ pada DG menunjukkan adalah gugus alkil (C-C), hal ini diperkuat dengan munculnya bilangan gelombang $1265.3 \mathrm{~cm}^{-1}$ yang merupakan gugus ester yang merupakan penghubung rantai karbon dalam senyawa selulosa. Menurut Shanmugarajah et al. (2015) daerah serapan 1420 menunjukkan adanya $-\mathrm{CH}_{2}$ yang berdeformasi dalam selulosa, pada sampel spektra dari DG muncul pada $1404.18 \mathrm{~cm}^{-1}$ sedangkan pada selulosa standar muncul pada bilanga gelombang $1427.32 \mathrm{~cm}^{-1}$. Pada bilanga gelombang 1600-1500 $\mathrm{cm}^{-1}$ mengindikasikan adanya vibrasi kerangka aromatic yang berasal dari lignin, pada sampel ditunjukkan pada bilangan gelombang $1527.62 \mathrm{~cm}^{-1}$ untuk DG (Moran et al., 2008). Spektra selulosa standar memiliki daerah serapan $1035 \mathrm{~cm}^{-1}$ sedangkan pada sampel DG pada bilangan gelombang $1064.71 \mathrm{~cm}^{-1}$ berkaitan dengan C-O-C (ikatan eter ) dari ikatan glikosidik (Liu \& Bai, 2005). Hal ini diperkuat dengan munculnya spektra dari DG dimana pada bilangan gelomabng $894.97 \mathrm{~cm}^{-1}$. Hal ini mengindikasikan adanya ikatan $\beta$ glikosida. Struktur kimia inilah yang menyebabkan selulosa tidak mudah larut dan bersifat kristalin sehingga tidak mudah terdegradasi oleh larutan kimia (Putera, 2012). Munculnya beberapa panjang gelombang pada sampel yang tidak ada pada standar selulosa seperti, pada panjang gelombang $1527.62 \mathrm{~cm}^{-1}$ untuk DG yang menunjukkan adanya gugus $\mathrm{N}-\mathrm{O}$ yang kuat. Adanya gugus lain dalam sampel mempengaruhi kandungan selulosa didalam sampel.

\section{Pengujian $X$-ray Difractiion (XRD)}

Pengujian XRD dilakukan untuk mengetahui dua tipe data, yaitu kualitatif dan kuantitatif dengan mengetahui posisi $2 \theta$ pada tiap puncak yang terdeteksi oleh XRD. Dengan mengetahui besarnya intensitas relatif deretan puncak-puncak difraksi tersebut maka dapat diketahui senyawa penyusun material tersebut. 

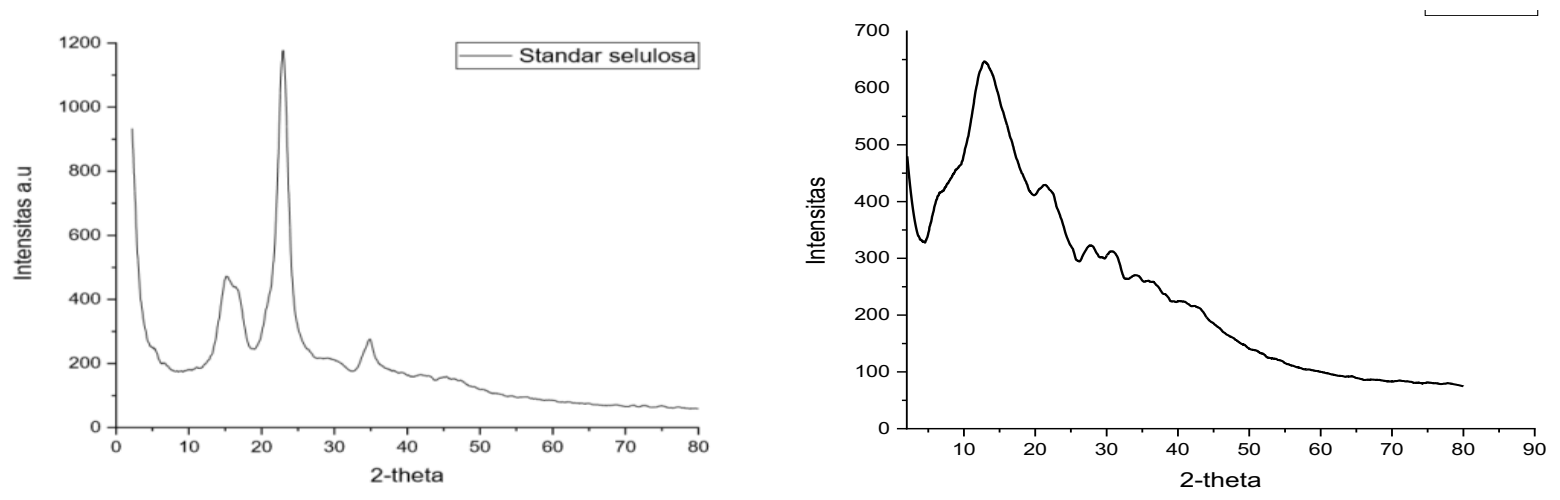

Gambar 2. Pola difraktogram XRD dari tepung daging buah pala (DG) dan tepung mikrokristalin selulosa.

Tabel 3. Karakteristik kristalitas dari tepung DG dan standar selulosa.

\begin{tabular}{ccccc}
\hline Sampel & $\begin{array}{c}\text { Sudut puncak } \\
\text { difraksi }\left(2 \theta^{0}\right)\end{array}$ & $\begin{array}{c}\text { Intensitas } \\
\text { puncak }\end{array}$ & FWHM & $\begin{array}{c}\text { Kristalinitas } \\
(\%)\end{array}$ \\
\hline DG & $13,2 / 21,48$ & $908 / 498$ & $2,34 / 2,92$ & 49,85 \\
$\begin{array}{c}\text { Standar } \\
\text { selulosa }\end{array}$ & $15,04 / 22,72$ & $500 / 1260$ & $4,97 / 1,6$ & 60,29 \\
\hline
\end{tabular}

Berdasarkan pada Gambar 2 pola difraktogram DG memiliki puncak 2-theta yang menonjol dan berdasarkan pola difraktogramnya DG memiliki pola yang mirip dengan pola difraktogram dari standar mikrokristalin selulosa. Berdasarkan juga Tabel 3 diketahui bahwa sampel daging buah pala memilki puncak 2-theta yang menonjol pada $13.2^{0}$ dan $21.48^{0}$ dengan nilai Full Width Half Maximum (FWHM) sebesar 2.34 / 2.92. Jika dibandingkan dengan difraktogram dari mikrokristalin selulosa menunjukan puncak 2-theta yang menonjol pada $22.72^{\circ}$ dan $15.04^{\circ}$ dengan persen kristalinitas standar mikrokristalin selulosa sebesar $60.3 \%$. berdasarkan pada Tabel 3 nilai kristalinitas sampel tidak terlalu berbeda dengan standar mikrokristalin selulosa. Hal ini diduga karena puncak 2-theta yang menonjol pada $22.72^{\circ}$ merupakan puncak yang dihasilkan oleh selulosa. Hal ini berarti sampel memiliki kandungan selulosa yang hamper mirip dengan standar selulosa dengan puncak 2-theta yang menonjol pada $21.48^{0}$.

\section{Pengujian Particle size analysis (PSA)}

Hasil pengujian PSA dalam bentuk distribusi ukuran partikel sehingga dapat mengambarkan keseluruhan kondisi sampel. Hal ini memungkinkan dapat menghitung distribusi ukuran partikel secara menyeluruh. Distribusi ukuran partikel daging buah pala dapat dilihat pada Gambar 3.

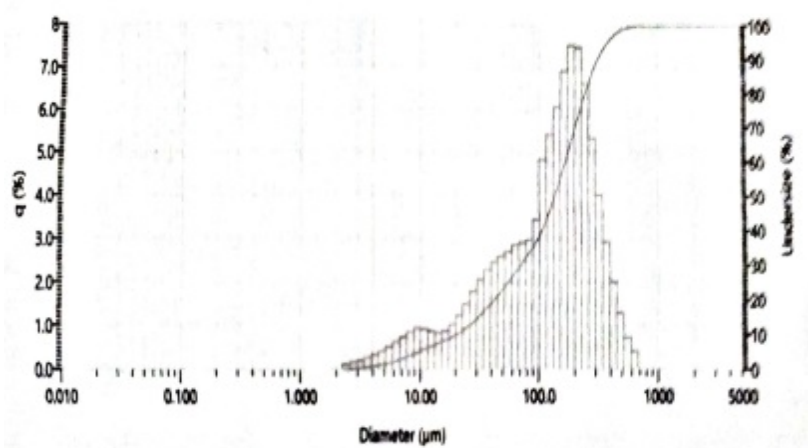

Gambar 3. Grafik distribusi ukuran partikel dari tepung daging buah pala.

Distribusi ukuran partikel dan nilai span dari sampel dapat dilihat pada Tabel 4. Nilai span merupakan jarak atara titik 10 persen dan 90 persen atau sama dengan nilai median.

Tabel 4. Distirbusi ukuran partikel tepung daging buah pala

\begin{tabular}{ll}
\hline Ukuran partikel & \\
\hline $\mathrm{D}_{0.1}(\mu \mathrm{m})$ & 20,79 \\
$\mathrm{D}_{0.5}(\mu \mathrm{m})$ & 137,08 \\
$\mathrm{D}_{0.9}(\mu \mathrm{m})$ & 314,66 \\
$\operatorname{Span}^{\mathrm{a}}(\mu \mathrm{m})$ & 2,14 \\
\hline
\end{tabular}

Berdasarkan Tabel 4 diketahui bahwa sampel dapat dimikronisasi menggunakan alat milling Fomac tipe FCT-Z200 sehingga mendapatkan ukuran particle $137.08 \mu \mathrm{m}$. Kecil besarnya nilai span menunjukkan tingkal keseragaman ukuran partikel sampel. Semakin kecil nilai span maka semakin seragam ukuran 
partikel sampel dengan distribusi ukuran partikel pada grafik yang dihasilkan lebih rapat.

\section{Ekstraksi}

Pada penelitian ini metode ekstraksi yang digunakan adalah ekstraksi maserasi dengan pelarut etanol $80 \%$ karena metode ini umum digunakan dan lebih sederhana. Proses maserasi melalui perendaman sampel akan memecah dinding sel dan pelarut masuk ke rongga sel yang mengandung zat-zat aktif sehingga zat aktif tersebut akan larut (Harmita, 2008). Ekstraksi tepung daging buah pala dengan pelarut etanol $80 \%$ dipakai untuk mendapatkan ekstrak fenolik bebas (EFB) dari sampel sedangkan residu hasil ekstraksi fenolik bebas dihidrolisis menggunakan asam dan basa untuk mendapatkan ekstrak fenolik terikat (EFT). Tabel 5 menunjukkan rendemen dari ekstrak dan kandungan total fenolik.

Tabel 5. Rendemen hasil ekstraksi dan total kandungan fenolik dari ekstrak

\begin{tabular}{lcc}
\hline Jenis ekstrak & $\begin{array}{c}\text { Rendemen } \\
(\%)\end{array}$ & $\begin{array}{c}\text { Total fenolik } \\
(\mu \mathrm{g} / \mathrm{mL})\end{array}$ \\
\hline EFB & 19,48 & $50,09 \pm 0,67^{\mathrm{a}}$ \\
EFT & 22,15 & $29,71 \pm 0,67^{\mathrm{b}}$ \\
\hline
\end{tabular}

Keterangan: $\quad$ EFB $=$ Ekstraksi Fenolik Bebas; EFT $=$ Ekstrak Fenolik Terikat

Berdasarkan Tabel 5 hasil rendemen ekstrak fenolik bebas $(19,48 \%)$ dengan total fenoliknya sebesar $50,09 \mu \mathrm{g} / \mathrm{mL}$ dan untuk rendemen fenolik terikat $22.15 \%$ dengan total fenolik $29,71 \mu \mathrm{g} / \mathrm{mL}$. Perbedaan hasil rendemen daging buah pala dipengaruhi oleh banyaknya komponen yang masih terikat kuat dengan karbohidrat sehingga proses ekstraksi fenolik bebas hanya sebagian yang terekstraksi. semakin rendah nilai rendemen yang didapatkan dari hasil ektraksi semakin rendah pula kandungan total fenoliknya. Tingginya kandungan total fenolik terikat pada sampel diduga bahwa sampel setelah dihidrolisis dengan asam dan basa masih memiliki senyawa aktif didalamnya. Sejalan dengan penelitian Parra et al. (2007) bahwa proses hidrolisis dari residu hasil ekstrak (ekstrak fenolik terikat) ternyata masih banyak kandungan senyawa fenolik yang terkandung dalam residu tersebut.

\section{Penentuan kandungan aktivitas antioksidan}

Penentuan kandungan aktivitas antioksidan di lakukan dengan metode pengujian radikal 1,1difenil-2-pikrilhidrazil (DPPH). Pengujian penangkal radikal bebas DPPH menggunakan spektrometer yang dilakukan dengan mereaksikan ekstrak dengan larutan DPPH. Persen penangkal radikal bebas diperoleh dari hasil bagi antara nilai absorbansi sampel dengan nilai absorbansi kontrol dikali dengan 100\%. Kandungan aktivitas antioksidan dapat dilihat pada Tabel 6 .

Tabel 6. Kandungan aktivitas antioksidan tepung daging buah pala

\begin{tabular}{cc}
$\begin{array}{c}\text { Jenis } \\
\text { ekstrak }\end{array}$ & $\begin{array}{c}\text { Aktivitas penangkal radikal } \\
\text { bebas DPPH }(\%)\end{array}$ \\
\hline EFB & $66,20 \pm 0,33$ \\
EFT & $50,97 \pm 0,93$ \\
\hline
\end{tabular}

Dari Tabel 6 tepung daging buah pala memiliki kandungan aktivitas antioksidan dari ekstrak fenolik bebas lebih besar dibandingkan dengan ekstrak fenolik terikat. Hasil ini dipengaruhi oleh kemampuan gugus fenol untuk berpasangan dengan radikal bebas dengan cara mendonorkan atom hidrogennya melaui transfer elektron, proses ini mengubah fenol menjadi radikal fenoksil. Radikal fenoksil ini dapat menstabilkan diri melaui proses resonansi sehingga tidak terjadi reaksi berantai pembentukan radikal. Dan juga dipengaruhi oleh tingginya total fenolik ekstrak fenolik bebas dibandingkan dengan fenolik terikat karena besarnya aktivitas antioksidan pada suatu sampel sangat dipengaruhi oleh kandungan fenolik yang terdapat didalamnya.

\section{Penentuan kapasitas penangkal ion nitrit}

Nitrit merupakan ion reaktif yang dapat bereaksi dengan amina sekunder pada asam dan membentuk senyawa nitrosamine yang karsinogenik. Dimana reaksi ini berlangsung dalam usus atau lambung. Senyawa nitrosamine yang terbentuk dapat dihambat oleh senyawa fenolik. Hasil analisis kapasitas penangkal nitrit dari ekstrak fenolik tepung daging buah pala disajikan pada Tabel 7.

Tabel 7. Kapasitas penangkal ion nitrit ekstrak fenolik tepung daging buah pala

\begin{tabular}{cc}
\hline $\begin{array}{c}\text { Jenis } \\
\text { ekstraksi }\end{array}$ & $\begin{array}{c}\text { Aktivitas penangkal ion } \\
\text { nitrit }(\%)\end{array}$ \\
\hline EFB & $28,14 \pm 0,03$ \\
EFT & $20,90 \pm 0,02$ \\
\hline Dari Tabel & 7 serbuk daging buah pala \\
memiliki kapasitas penangkal nitrit dari ekstrak \\
enolik bebas lebih besar dibandingkan dengan \\
kstrak fenolik terikat. Hasil ini dipengaruhi oleh
\end{tabular}


tingginya total fenolik ekstrak fenolik bebas dibandingkan dengan fenolik terikat karena semakin tinggi kandungan fenolik dalam sampel maka semakin tinggi juga kemampuan suatu sampel untuk menangkal ion nitri. Ini juga dipengaruhi oleh senyawa fenolik yang prooksidan yang berinteraksi dengan radikal nitrit mempercepat proses oksidasi lipid. Prooksidan merupakan sifat senyawa radikal bebas yang mendorong peroksidasi lipid sel (Skrzdlewska et al., 2004).

\section{KESIMPULAN}

Daging buah pala memilkik karakteristik fisik yang dianalisis menggunakan spektrofotometer FTIR menunjukkan adanya daerah serapan gugus $-\mathrm{OH},-\mathrm{CH},-\mathrm{CH}_{2}, \mathrm{C}-\mathrm{O}-\mathrm{C}$ yang merupakan identifikasi adanya selulosa pada sampel. Hasil difraksi sinar-X pada tepung daging buah pala memiliki puncak yang hamper sama dengan standar mikrokristalin selulosa yang berarti sampel memiliki struktur selulosa. Hasil karakterisasi secara fisik dengan particle size analayzer menunjukkan ukuran distribusi partikel tepung daging buah pala $(137,08 \mu \mathrm{m})$. Sedangkan karakterisasi kimia menunjukkan komposisi kimia dari daging buah pala seperti air $(9.11 \%)$, abu $(3.43 \%)$, lemak $(1.81 \%)$, protein $(4.04 \%)$, serat kasar $(17.57 \%)$, serat pangan tak larut $(48.61 \%)$, serat pangan terlarut $(1.67 \%)$, serat pangan total $(50.28 \%)$, hemiselulosa $(10.72 \%)$, selulosa (15.66\%) dan lignin (19.09\%). Aktivitas antioksidan menunjukkan bahwa ekstrak fenolik bebas daging buah pala lebih besar dibandingkan dengan ekstrak fenolik terikat daging buah pala dan aktivitas penangkal nitrit dari daging buah pala menunjukkan bahwa ekstrak fenolik bebas daging buah pala lebih besar dibandingkan dengan ekstrak fenolik terikat daging buah pala yang dipengaruhi oleh proses ekstraksi dari sampel.

\section{DAFTAR PUSTAKA}

AOAC. 1995. "Official methods of analysis of association of official analytical chemist". AOAC International. Virginia USA.

Arrizqiyani, T., Sri, S. \& Mila, M. 2018. Aktivitas antibakteri daging buah dan daun pala (Myristica Fragrans) terhadap Escherichia Coli. Jurnal Vokasi Kesehatan, 4(2), 91-94.
Blagden, N., de Matas, M., Gavan, P.T. \& York, P. 2007. Crystal engineering of pharmaceutical ingredient to improve solubility and dissolution rates. Elsevier, 59(7), 617-630.

Chau, C.F., Wu, S.H. \& Yen, G.C. 2007. The development of regulations for food nanotechnology. Trends Food Science Technology. 18(5), 269-280.

Datta, R. 1981. Acidogenic fermentation of lignocellulose-acid yield and conversion of components. Biotechnology and Bioengineering, 23(9), 2167-2170.

Fidriany, Ruslan \& Ibrahim. 2004. Karakteristik simplisia dan ekstrak daging buah pala (Myristica frangrans Houtt). Journal Acta Pharma-ceutica Indonesia, 29(1), 55-60.

Harmita \& Radji, M. 2008. Buku Ajar Analisis Hayati. EGC. Jakarta.

Janeiro, P. \& Brett, A.M.O. 2004. Catechin electrochemical oxidation mechanisms. Journal Analytica Chemica Acta, 518(12), 109-115.

Jeong, S.M., Kim, S.Y., Kim, D.R., Jo, S.C., Nam, K.C., Ahn, D.U. \& Lee, S.C. 2004. Effect of heat treatment on theantioxidant activity of extracts from citrus peels. Journal of Agricultural and Food Chemistry, 52(11), 3389-3393.

Marzuki, I., Uluputty, M.R., Sandr, A.A. \& Memen, S. Karakteristik morfoekotipe dan proksimat pala Banda (Myristica fragrans Houtt). Jurnal Agronomi Indonesia, 36(2), 145- 151.

Molyneux, P. 2004. The use of the stable free radical diphenylpicryl-hydrazyl (DPPH) for estimating antioxidant activity. Journal of Science Technology, 26(2), 211-219.

Parra, L.D.C., Saldivar, S.O.S. \& Liu, H.R. 2007. Effect of processing on the photochemical profile and antioxidant activity of corn for production of masa, tortillas, and tortilla chips. Journal of Algicultural and Food Chemistry, 55(10), 4177-4183.

Skrzdlewska, E., Ostrowska, J., Luczaj, W., Kasacka, I. \& Rozanski, A. 2004. Green tea againts ethano-induced lipid peroksidase in 
rat organs. Journal of Clinical Medicine, 32(1), 25-32.

Zhang, L., Xu, H. dan Li, S. 2009. Effects of micronization on properties of Chaenomeles Sinensis (Thouin) Koehne fruit powder. Innovative Food Science \& Emerging Technologies, 10(4), 63-637. 